\title{
Aktivitas dan Teritori Ruang Publik Kost Sebagai Interaksi Sosial
}

\author{
La Pande Jurumai \\ Program Studi Arsitektur, Fakultas Teknik, Universitas Muhammadiyah Kendari \\ e-mail: pande.jurumai09@gmail.com
}

\begin{abstract}
Abstrak
Penghuni kost selalu membutuhkan ruang dalam memenuhi aktivitas kesehariannya. Meskipun secara fungsi rumah kost didesain untuk memenuhi kebutuhan penghuninya yang bersifat sementara, namun bukan berarti fasilitas pada area kost tidak terpenuhimisalnya ruang televisi, ruang masak dan fasilitas lainnya. Dalam arsitektur, fasilitas kost bukan hanya berbicara kenyamanan dalam unit ruang saja melainkan unit ruang dalam skala meso juga harus diperhatikan oleh pemilik kost. Namun dalam kenyataannya masih banyak kost khususnya kost keluarga tidak terlalu memperhatikan fasilitas tersebut, sehingga penghuni kost lebih berinisiatif dalam menciptakan ruang sendiri secara tidak langsung membangun teritori dalam lingkup ruang mereka sendiri.Tanpa disadari penghuni kost telah memutus jalur interaksi antara sesama penghuni kost, yang harusnya dapat dikendalikan oleh pemilik kost.
\end{abstract}

Kata Kunci: Aktivitas, teritori, penghuni kost, interaksi sosial

\section{PENDAHULUAN}

Ruang publik merupakan ruang bersama yang dimanfaatkan untuk mewadahi aktivitas penggunanya. Pemanfaatan ruang bersama di dalam dan sekitar kawasan kost-kostan merupakan hal biasa dan sering kita temui di kota Yogyakarta dan kota-kota besar lainnya. Jika ruang bersama kurang diwadahi akan banyak permasalahan yang terjadi, baik antara sesama penghuni kost, penghuni dengan pemilik kost, dan bahkan antara penghuni dengan masyarakat lainnya. Permasalahan tersebut sering terjadi, untuk kasus dalam internalkost-kostansendiri umunya terjadi karena kurangnya fasilitas sertaruang bersama sebagai area berkumpul yang seharusnya menjadi tempat saling berinteraksi, bersosialisasi dan berkomunikasi. Ruang bersama tersebut dapat berupa taman, jalan, tempat jemur, ruang masak, mencuci dan kakus.

Selain fasilitas ruang bersama, perlu kontrol sosial di lingkungan kost-kostan yang 
semestinya setting ruang diatur oleh pemilik kost agar tidak terjadi kontak secara fisik maupun kontak yang bersifat psikologis. Jika hal tersebut tidak diindahkan, maka banyak hal yang akan terjadi dan dirasakan oleh penghuni kost bahkan masyarakat disekitar kost, misalnya kurang nyaman dalam beraktivitas akibat gangguan dari penghuni lainnya.Tujuan PenelitianUntuk mengkaji teritori dan aktivitas penghuni pada area asrama, dengan kasus asrama milik $\mathrm{Hj}$. Sri Murwani.

\subsection{Tinjauan Teori}

\subsubsection{Ruang Komunal}

Ruang komunal merupakan ruang bersama tempat berkumpul dan berinterkasi, bermain dan berolahraga, dan melaksanakan acara/hajatan (Darmiati, 2000). Ruang komunal meruapakan ruang yang digunakan sebagai ruang sosial dan dapat digunakan oleh kelompok masysarakat dalam memenuhi aktivitasnya (Weilman \& Leighton: 1979, Alexander: 1997, Newman:1990, Herlianto: 1986).

Carr (1992) melihat ruang terbuka publik sebagai ruang milik bersama, tempatmasyarakat melakukan aktivitas fungsional dan ritualnya dalam suatu ikatan komunitas,baik kehidupan sehari-hari maupun dalam perayaan berkala yang telah ditetapkan sebagai sesuatu yang terbuka, tempat masyarakat melakukan aktivitas pribadi dankelompok.

Menurut Carmona (2003) ada beberapa faktor yang dapat dilihat dari hubungan pengguna aktivitas dengan ruang terbuka publik itu sendiri, yaitu:

a) Comfort, kenyamanan adalah faktor penting pada ruang publik. Lama waktu yang dihabiskan oleh pengunjung merupakan indikator dari kenyamanan. Rasa nyaman dipengaruhi oleh faktor lingkungan (terhindar dari matahari, angin, dan lain-lain), kenyamanan fisik (tempat duduk yang nyaman, dan lain-lain), dan kenyamanan sosial dan psikologis. Terakhir adalah tergantung dari karakter dan kualitas dari ruang tersebut. Carr (1992) beragumentasi bahwa ini merupakan kebutuhan penting untuk memperluas pengalaman pengunjung dalam ruang publik. Rasa aman, dimana seseorang tidak merasa was-was. Rasa nyaman dapat dipengaruhi oleh desain fisik dari sebuah ruang yang ditujukan sebagai strategi marketing.

b) Relaxation, walau nyaman secara psikologis haruslah muncul sebelum relaxation. Relaxationsendiri berarti lebih mengarah tenangnya badan serta pikiran (Carr, 1992). Padaruang publik, natural elements seperti pohon, rumput, elemen air dan pembatasjalan yang membatasi bagian dalam ruang publik membuat pengunjung lebih mudahuntuk relaxed. 
Elemen-elemen estetika yang juga dapat menutup akses secara visual,memberikan masalah keamanan, dan membuat pengunjung tidak inginmemanfaatkan ruang tersebut. Dari semua aspek desain, sangat penting untukmenyeimbangkan semuanya.

c) Passive engagement, penggunaan pasif yang dilakukan oleh pengguna ruang publik adalah mengamatilingkungan. Setting spasial ruang publik harus memungkinkan pengguna untukberhenti bergerak dan menikmati suasana yang didukung oleh perabot lansekap yang memadai.

d) Active engagement, terjadi dalam bentuk aktivitas yang secara langsung melibatkan pengguna. Interaksi yang terjadi dalam bentuk komunikasi antar pengguna ini dapat terjadi secara spontan dikarenakan adanya sesuatu yang menarik.

e) Discovery, pengalaman ruang yang beragam akan meningkatkan ketertarikan orang untuk terlibat di suatu ruang publik. Pengalaman ruang ini akan terwujud berupa desain lansekap yang unik, penampilan panorama alami yang menarik, pertunjukan kesenian, kios dan lainlain.

\subsubsection{Teritorialitas}

Sommer (1966), mengatakan teritori adalah wilayah yang dikuasai oleh seseorang, keluarga, atau secara kolektif dari tatap muka lainnya. Kontrol teritori terkontrol dalam kepemilikan secara aktual atau potensial dari pada bukti benturan fisik atau tingkat agresif pada tingkat manusia.

Perbedaan ruang personal dengan teritorialitas menurut pendapat Sommer dan de War (1963), bahwa ruang personal dibawa kemanapun seorang pergi, sedangkan teritori memiliki implikasi tertentu yang secara geografis merupakan daerah yang tidak berubah-ubah.

Altman (1975), mendevinisikan perilaku teritorial adalah mekanisme pengaturan batas diri/batasan lain yang melibatkan personalisasi atau penandaan suatu tempat atau objek dan komunikasi yang "dimiliki" oleh seseorang atau kelompok.Altman (1975), membagi teritorialitas menjadi tiga, yaitu:

a. Primary territories, jenis teritori ini dimiliki serta dipergunakan secara khusus bagi pemiliknya. Pelanggaran terhadap teritori utama ini akan mengakibatkan timbulnya perlawanan dari pemiliknya dan ketidakmampuan untuk mempertahankan teritori utama ini akan mengakibatkan masalah yang serius terhadap aspek psikologis pemiliknya, yaitu dalam 
hal harga diri dan identitasnya. Yang termasuk dalam teritori ini adalah ruang kerja, ruang tidur, pekarangan, wilayah negara, dan sebagainya.

b. Secondary territories. Teritori ini lebih longgar pemakaiannya dan pengontrolan oleh perorangan. Teritori ini dapat digunakan oleh orang lain yang masih di dalam kelompok ataupun orang yang mempunyai kepentingan kepada kelompok itu. Sifat dari secondary territories adalah semi-publik, yang termasuk dalam teritorial ini adalah sirkulasi lalulintas dalam kantor, toilet, zona servis dan sebagainya.

c. Public territories, teritorial umum dapat digunakan oleh setiap orang dengan mengikuti aturan-aturan yang lazim di dalam masyarakat dimana teritorial umum itu berbeda. Teritorial umum dapat dipergunakan secara sementara dalam jangka waktu lama maupun singkat. Contoh dari teritorial umum ini adalah taman kota, tempat duduk dalam bus kota, gedung bioskop, ruang kuliah dan sebagainya. Berdasarkan pemakaiannya, teritorial umum dapat dibagi menjadi tiga: stalls, turns, dan use space.

Teritorialitas berfungsi sebagai proses sentral dalam personalisasi, agresi, dominasi, koordinasi dan kontrol.

a. Personalisasi dan penandaan, seperti memberi nama, tanda atau menempatkan di lokasi strategis, bisa terjadi tanpa kesadaran teritorialitas. Seperti membuat pagar batas,memberi nama kepemilikan. Penandaan juga dipakai untuk mempertahankan haknya di teritori publik, seperti kursi di ruang publik ataupun naungan.

b. Agresi, pertahanan dengan kekerasan yang dilakukan seseorang akan semakin keras bila terjadi pelanggaran di teritori primernya dibandingkan dengan pelanggaran yang terjadi ruang publik. Agresi bisa terjadi disebabkan karena batas teritori tidak jelas.

c. Dominasi dan kontrol, umumnya banyak terjadi di teritori primer. Kemampuan suatu tatanan ruang untuk menawarkan privasi melalui kontrol teritori menjadi penting.

\subsubsection{Aktivitas}

Menurut Trancik (1986), keterpaduan tatanan fisik dan pola aktivitas dalam perancangan spasial ruangterbuka kawasan sebagai ruang publik akan memberikan komposisi solid void yang jelas pada ruang, hubungan antar bagian ruang yang terorganisir dan terstruktur dengan baik, serta rancangan yang tanggapterhadap kebutuhan pengguna.

Dalam beraktivitas, akan dipengarui oleh setiap tatanan fisik yang akan memicu perilaku tertentu. Sebagai sebuahlingkungan fisik dan sosial, sebuah kawasan akan selalu memiliki 
hubungan timbal balik (synomorphy) antarastanding pattern of behavior dengan millieu (Lang, 1987, Barker, 1968).

\subsubsection{Interaksi sosial}

Interaksi sosial merupakan suatu hubungan timbal balik yang saling mempengaruhi antara individu, kelompok sosial, dan masyarakat. Interaksi sosial merupakan suatu proses di mana manusia melakukan komunikasi dan saling mempengaruhi dalam tindakan maupun pemikiran. Kurangnya komunikasi antara sesama penghuni dan atau dengan pemilik kost juga dapat mempengaruhi interaksi sosial. Hal ini akan mengakibatkan interaksi sosial menurun (Hardywinoto dan T., 2005).

Adapun Basrowi (2015) mengemukakan interaksi sosial adalah hubungan dinamis yang mempertemukan orang dengan orang, kelompok dengan kelompok, maupun orang dengan kelompok manusia. Bentuknya tidak hanya bersifat kerjasama, tetapi juga berbentuk tindakan, persaingan, pertikaian dan sejenisnya.

Louis (Toneka, 2000) mengemukakan interaksi sosial dapat berlangsung apabila memiliki beberapa aspek berikut : a) adanya suatu dimensi waktu yang meliputi masa lampau, kini dan akan datang, yang menentukan sifat dan aksi yang sedang berlangsung; b) adanya jumlah perilaku lebih dari seseorang; c) adanya tujuan tertentu, tujuan ini harus sama dengan yang dipikirkan oleh pengamat.

Menurut Gerungan (2006), faktor-faktor yang mempengaruhi terjadinya interaksi sosial yaitu :

a. Imitasi, mempunyai peran yang penting dalam proses interaksi. Salah satu segi positif dari imitasi adalah dapat mendorong seseorang untuk mematuhi kaidah dan nilai-nilai yang berlaku. Tetapi imitasi juga dapat menyebabkan hal-hal negatif, misalnya yang ditirunya adalah tindakan-tindakan yang menyimpang dan mematikan daya kreasi seseorang.

b. Sugesti, hal ini terjadi apabila individu memberikan suatu pandangan atau sikap yang berasal dari dirinya yang kemudian diterima pihak lain. Berlangsungnya sugesti bisa terjadi pada pihak penerima yang sedang dalam keadaan labil emosinya sehingga menghambat daya pikirnya secara rasional. Biasanya orang yang memberi sugesti orang yang berwibawa atau mungkin yang sifatnya otoriter.

c. Identifikasi, sifatnya lebih mendalam karena kepribadian individu dapat terbentuk atas dasar proses identifikasi. Proses ini dapat berlangsung dengan sendirinya ataupun disengaja sebab individu memerlukan tipe-tipe ideal tertentu di dalam proses kehidupannya. 
d. Simpati, merupakan suatu proses dimana individu merasa tertarik pada pihak lain. Didalam proses ini perasaan individu memegang peranan penting walaupun dorongan utama pada simpati adalah keinginan untuk kerjasama.

Partowisastro (2003) mengemukakan pendapat tentang bentuk-bentuk interaksi sosial itu pada dasarnya terbagi dalam dua proses, yaitu :

a. Proses-proses asosiasi; yang terbagi menjadi :

a) Akomodasi, merupakan suatu proses penyesuaian aktivitas-aktivitas seseorang atau kelompok yang berlawanan menjadi sejalan.

b) Assimilasi, yaitu suatu proses yang memiliki ciri pembentukan persamaan sikap, pandangan, kebiasaan, pikiran dan tindakan sehingga seseorang atau kelompok itu cenderung menjadi satu, mempunyai perhatian dan tujuan-tujuan yang sama.

c) Akulturasi, dari segi teori kebudayaan merupakan suatu aspek dari perubahan kebudayaan.

b. Proses-proses dissosiasi; yang terbagi menjadi :

a) Kompetisi, merupakan suatu persaingan yang terjadi antara perorangan atau kelompok dalam mencapai dan mendapatkan suatu tujuan tertentu.

b) Kontraversi, merupakan suatu perbedaan-perbedaan pandangan, ide dan tujuan yang terjadi pada satu orang atau lebih sehingga menimbulkan pertentangan.

c) Konflik, yaitu suatu ketegangan yang terjadi perorangan atau kelompok dikarenakan adanya perbedaan pandangan tentang suatu masalah maupun penyelesaiannya.

Skema hubungan antara ruang komunal, teritorialitas, aktivitas, dan interaksi sosial, yaitu sebagai berikut:

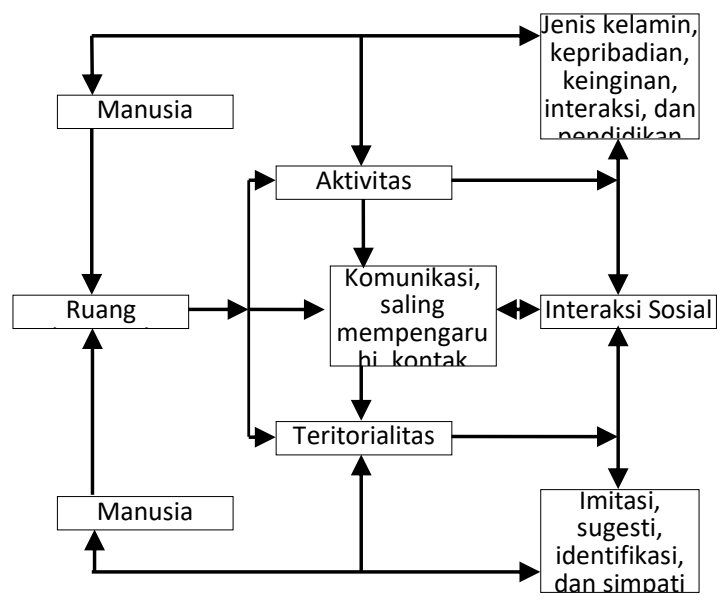

Gambar 1. Skema hubungan 


\section{METODE PENELITIAN}

Penelitian dilakukan bersifat deskriptif, yaitu mengandalkan pengamatan dan wawancara.Pendekatan yang dilakukan dalam penelitian ini menggunakan behavioral mapping. Behavioral mapping digambarkan dalam bentuk tingkat intensitas penggunaan ruang bersama pada area kost dimana penghuni kost melakukan berbagai aktivitasnya dengan tujuan untuk menggambarkan frekuensi penggunaa ruang tersebut di dalam sebuah peta dan mengidentifikasi batas teritori sebagai kontrol sosial dilingkungan kost. Behavioral mapping yang digunakan adalah place centered mapping. Place centered mapping digunakan untuk mengetahui bagaimana manusia memanfaatkan, menggunakan atau mengakomodasi perilaku dan aktivitasnya dalam suatu waktu dan tempat tertentu.

\subsection{Waktu Penelitian}

Pengamatan dilakukan setiap hari saat weekends yaitu hari sabtu dan minggu dan weekdays yaitu hari senin sampai dengan jum'at. Untuk hari sabtu dan minggu waktu pengamatan dilakukan 4 tahapan waktu pada pagi hari pukul 06.00-08.00, siang pukul 11.0013.00, sore pukul 16.00-18.00, dan malam pukul 18.00 keatas sedangkan saat weekdays pengamatan hanya dilakukan dua tahapan waktu pada pagi dan sore hari saja. Pengamatan dilakukan dalam waktu yang berbeda bertujuan untuk memudahkan dalam pengumpulan data pola aktivitas dan ruang bersama mana saja yang digunakan dalam berinteraksi.

\subsection{Data dan Lokasi Penelitian}

Lokasi penelitian adalah rumah kost $\mathrm{Hj}$. Sri Murwani yang terletak di Jl. Selokan mataram, kutu tegal, popongan, Mlati.Rumah kost ini terdiri dari penghuni dengan status bujang dan dengan status berkeluarga. Untuk memudahkan dalam pengumpulan data, sehingga dilakukan pengumpulan data dengan membagi unit kost menjadi tiga zona amatan ruang bersama dengan unit kamar, fasilitas dan karakteristik ruang yang berbeda-beda. Hal tersebut dilakukan untuk memudahkan dalam pengumpulan data, serta fokus dari penelitian ini adalah menganalisis ruang bersama yang digunakan oleh penghuni kost/asrama.

Tabel di bawahmenunjukkan perbedaan unit hunian dari segi harga, fasilitas dan jumlah penghuni. Ketiga hal tersebut yang membedakan perlakuan terhadap setiap calon penghuni kost yang akan menyewa unit kamar yang diinginkan. 
Tabel 2.1 Pembagian Zoning Rumah Kost

\begin{tabular}{|c|c|c|c|c|}
\hline $\begin{array}{c}\text { Zona Ruang } \\
\text { Bersama }\end{array}$ & Unit/Penghuni & Pekerjaan & Biaya/Bulan & Ruang bersama \\
\hline Zona I & Rumah tinggal & Pensiunan PNS & - & $\begin{array}{l}\text { - Parkir } \\
\text { - Teras rumah } \\
\text { - Tempat duduk } \\
\text { - Ruang } \\
\text { jemur }\end{array}$ \\
\hline Zona II & $\begin{array}{l}\text { Unit } 1 \\
(2.5 \mathrm{~m} \times 2.5 \mathrm{~m})=7 \text { unit } \\
\text { kamar dengan } 7 \text { orang } \\
\text { penghuni }\end{array}$ & $\begin{array}{l}\text { - Tata rias } \\
\text { - Wiraswasta } \\
\text { - Jualan di } \\
\text { warung }\end{array}$ & Rp. 300rb & $\begin{array}{l}\text { - Parkir } \\
\text { - Kamar mandi } \\
\text { - Ruang masak } \\
\text { - Tempat mencuci } \\
\text { - Tempat duduk }\end{array}$ \\
\hline & $\begin{array}{l}\text { Unit } 2 \\
(3 \mathrm{~m} \times 2.5 \mathrm{~m})=5 \text { unit } \\
\text { kamar dengan } \\
6 \text { orang penghuni }\end{array}$ & $\begin{array}{l}\text { - Wiraswasta } \\
\text { - Jualan }\end{array}$ & Rp. 450rb & $\begin{array}{l}\text { - Kamar mandi luar } \\
\text { - Ruang masak } \\
\text { - Tempat mencuci } \\
\text { - Ruang } \\
\text { jemur }\end{array}$ \\
\hline Zona III & $\begin{array}{l}\text { Unit } 3(3 \mathrm{~m} \times 3 \mathrm{~m})=5 \text { unit } \\
\text { kamar dengan8 orang } \\
\text { penghuni }\end{array}$ & $\begin{array}{l}\text { - Mahasiswa } \\
\text { - Jualan di } \\
\text { warung } \\
\text { - Distributor } \\
\text { - Rental motor }\end{array}$ & Rp. 600rb & $\begin{array}{l}\text { - Parkir } \\
\text { - Tempat mencuci } \\
\text { piring }\end{array}$ \\
\hline
\end{tabular}

Tiap zona memiliki ruang bersama, dan tiap ruang bersama tersebut berbeda-beda tempatnya. Selain itu, yang membedakan adalah pelaku yang menggunakan ruang bersama. Secara tidak langsung penghuni kost yang kamarnya berdekatan dengan ruang bersama tersebut membentuk teritori tersendiri, sehingga membatasi interaksi dengan penghuni yang terdapat pada zona-zona yang lain. 


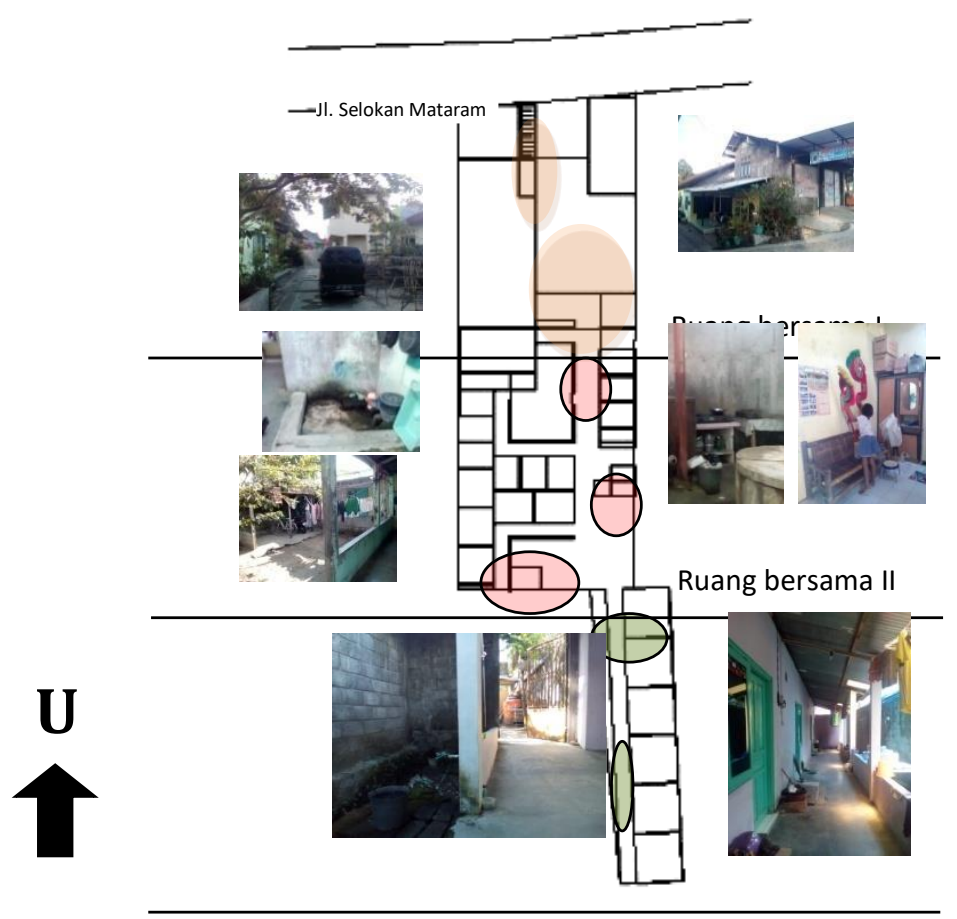

Gambar 2. Pemetaanruang bersama

Keterangan:

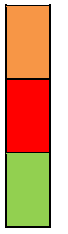
Ruang bersama I
(Area Rumah Pemilik Kost)
Ruang bersama II
(Area Asrama unit 1 dan 2)
Ruang bersama III
(Area Asrama unit 3)

Meski demikian terkadang terjadi penggunaan ruang bersama oleh penghuni di zona lain, misalnya ruang bersama MCK zona II digunakan oleh penghuni zona III hal ini terjadi karena kamar mandi zona III air bersihnya habis, sehingga memicu interaksi yang sifatnya positif bahkan dipandang tidak sopan oleh penghuni zona II.

a. Ruang bersama zona I

Merupakan rumah dari pemilik kost,untuk ruang bersamanya hanya terdapat di depan rumah yang digunakan sebagai tempat jemur dan sebagai tempat parkir. Ada fasilitas tempat duduk di teras depan rumah yang digunakan oleh pemilik kost dan anaknya yang telah berkeluarga. 


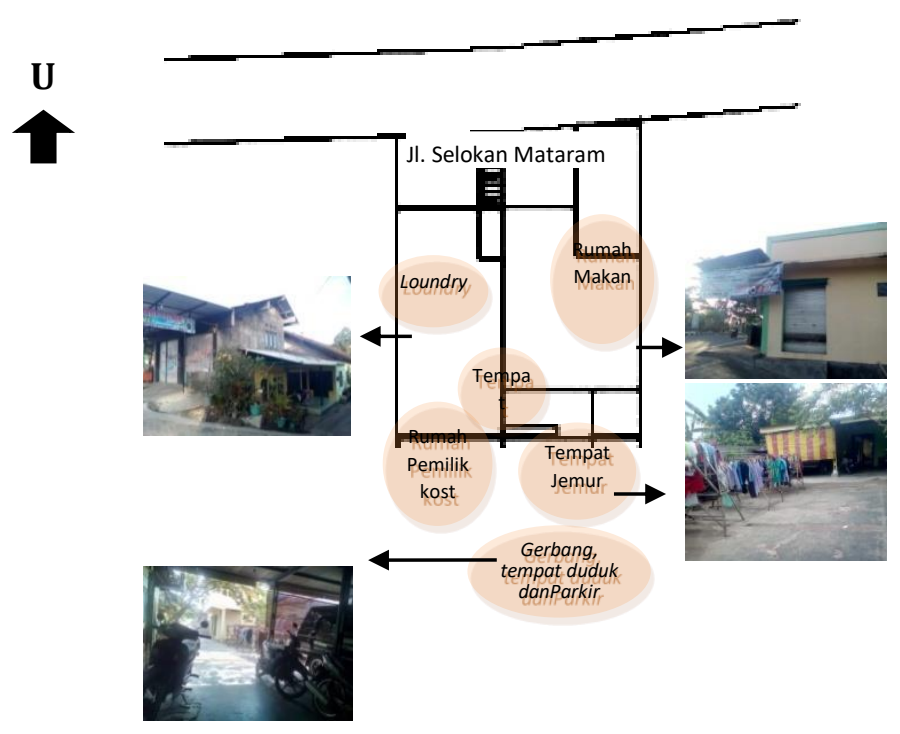

Gambar 3. Ruang bersama zona I

Selain itu ada fasilitas jasa yang di siapkan oleh pemilik kost yaitu loundry dan rumah makan yang dikelola oleh anak dari penghuni kos. Fasilitas parkir di zona I ini tidak diperuntukan kepada penghuni kost yang di zona II dan zona III karena masing-masing zona sudah memiliki tempat parkir sendiri untuk kendaraan roda dua, tidak untuk kendaraan roda empat. Namun terkadang ada penghuni dari zona III yang parkir pada zona ini.

b. Ruang bersama zona II

Zona ini tebagi atas dua unit kamar dengan harga dan ukuran ruang yang berbeda. Unit pertama terdiri atas tujuh unit kamar dengan penghuni sejumlah tujuh orang dengan harga yang cukup terjangjkau untuk seorang mahasiswa. Namun pada unit ini terdapat tiga unit kamar yang dijadikan satu unit kamar saja oleh anak kedua dari penghuni kost. Selain dari itu ada dua unit kamar yang dihuni oleh rumah tangga dengan satu anak (satu kamar untuk ayah dan ibu, serta satu kamar untuk anaknya). Sedangkan unit kamar yang sedikit lebih luas atau berukuran sedang untuk kost Hj. Sri Murwani ini memiliki unit kamar sebanyak lima unit kamar dan dihuni sebanyak enam orang.

Fasilitasnya sama yaitu kamar mandi luar dan tersedia ruang masak, tempat cuci pakaian dan cuci piring. Namun ruang tempat jemurnya yang berbeda, hal ini dibentuk berdasarkan teritori masing-masing penghuni kamar dengan menjemur di depan kamar masing-masing. 


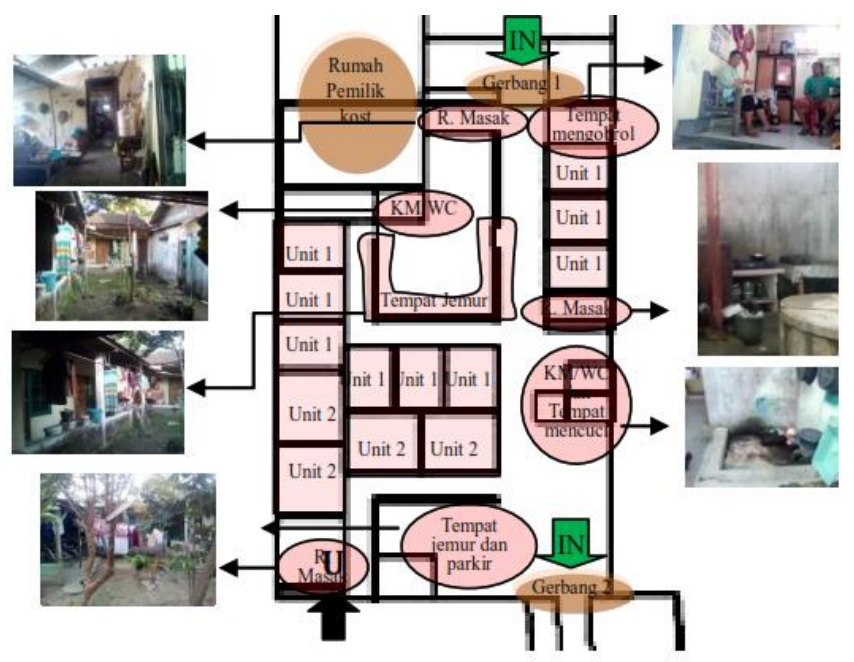

Gambar 4. Ruang bersamazona II

c. Ruang bersama zona III

Zona ini memiliki lima unit kamar, empat kamar dihuni oleh keluarga dan satu unit kamar dihuni oleh bujangan yang bekerja sebagai penyewa kendaraan roda dua (rental motor). Fasilitasnya yang disediakan kamar mandi dalam, tempat cuci piring dan parkir roda dua, sementara fasilitas lain seperti tempat masak dan ruang jemuran dibuat oleh penghuni atas inisiatif sendiri.

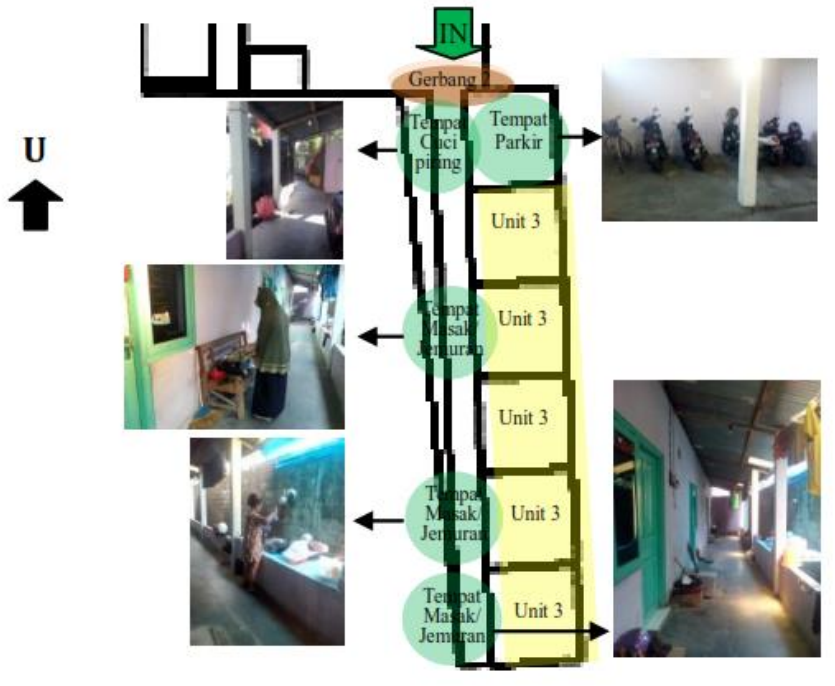

Gambar 5. Ruang bersama II

Untuk tempat masak dan jemuran ada di depan unit kamar masing-masing, sehingga membentuk teritori tersendiri yang dibatasi tiang kolom pada selasar. Tempat cuci piring berdekatan dengan parkir kendaraan, sehingga aksesnyapun cukup jauh untuk penghuni kamar yang berada di ujung kost. 


\section{d. Aktivitas Kost di Ruang Bersama}

Kondisi aktivitas kost yang diamati sesuai dengan waktu yang telah ditentukan, yaitu:

a) Weekdays pagi, saat hari kerja kondisi lokus amatan hampir tidak ada aktivitas dalam ruang publik seperti tempat cuci piring, tempat masak, dan tempat parkir khususnya zona III. Setelah melakukan wawancara dengan beberapa penghuni bahwa untuk pagi hari mereka lebih sering sarapan di luar kost sebelum pergi bekerja, mereka lebih aktif pergi bekerja setelah selesai shalat subuh. Namun ada penghuni pada ruang publik di zona II terutama ibu-ibu lebih nyaman beraktivitas setelah suami mereka pergi bekerja. Sedangkan di area penghuni kost pada zona I terkadang anak dari penghuni kost mencuci mobil atau kendaraan roda dua di area yang dibunakan sebagai halaman atau tempat parkir kendaraan.



Gambar 6. Kondisi aktivitas dan teritori kost.

b) Weekdays sore, yang lebih banyak beraktivitas pada sore hari adalah penghuni di zona II, hal tersebut dari penghuni kost yang duduk di area pintu gerbang pertama sambil mengobrol dengan anak penghuni kost.Selain itu, penghuni lain lebih memilih memasak.

c) Weekends pagi, untuk pagi hampir sama kondisi aktivitasnya dengan weekdays sore. Namun yang membedakan adalah pengguna ruang bersama terkadang saling bergantian menggunakan seperti tempat cuci piring, kamar mandi yang berada di luar, dan tempat 
jemuran.

d) Weekdays siang, pada siang hari penghuni kost lebih banyak beraktivitas di dalam kost masing-masing, dan ada juga yang memilih beribadah karena lokasi kost tidak jauh dari masjid untuk shalat. Selain itu, area zona I khususnya anak pemilik kost lebih beraktivitas di tempatloundry dan rumah makan miliknya.

e) Weekdays sore,biasanya pada waktu ini banyak aktivitas yang dilakukan penghuni kost namun di lokasi tampak biasa saja, hampir sama dengan kondisi aktivitas saat weekdays sore. Yang membuat sedikit lebih menyenangkan adalah aktivitas dari anak-anak dari penghuni kost yang banyak bermain pada area selasar.

f) Weekdays malam, waktu malam ini sebagai tambahan aktivitas dan yang lebih banyak menggunakan ruang adalah area zona III, lebih banyak menggunakan tempat masak, cuci piring, dan parkir. Berdasarkan wawancara, mereka memasak untuk suami mereka yang pulang dari bekerja. Selain itu penggunaan parkir pada zona ini karena untuk keamanan kendaraan para pekerja rental motor yang pulangnya selalu larut malam.

\section{HASIL DAN PEMBAHASAN}

Analisis dilakukan setelah peneliti melakukan pengamatan di area kost $\mathrm{Hj}$. Sri Murwani sesuai waktu amatan yang telah ditetapkan dan wawancara secara random terhadap penghuni dengan pertanyaan terbuka sehingga informasi yang diperlukan dapat mengalir tanpa ada unsur mengarahkan dalam menjawab pertanyaan.Berdasarkanfrekuensi aktivitas yang dilakukan penghuni kost setiap menggunakan ruang bersama seperti ruang memasak, tempat mencuci, MCK, ruang jemur, dan tempat parkir sehinggadapat ditentukan batasan atau lingkup analisisnya hanya pada aktivitas padaruang bersama tersebut.

a. Memasak

Di lokasi amatan terdapat tiga tempat memasak yang disiapkan oleh pemilik asrama, sedangkan pada zona III tempat memasaknya ada karena inisiatif dari penghuni kost sehingga terdapat tiga tempat memasak.Penggunaan tempat memasak pada zona II cenderung menggunakan tempat memasak yang terdekat dan tidak jauh dari area kost yang telah ada. Namun lain halnya dengan penghuni kost dari zona III yang lebih memilih memasak di depan kamar masing-masing dengan membuat meja-meja untuk meletakkan alat masak. Dari ruang memasak yang terpisah antar zona, faktor comfort dan relaxation menjadi hal yang sangat 
penting sehingga dalam beraktivitas membentuk pola tertentu. Dari settiing fisik tempat masaknya, jarak dan ruangnya menjadi pemisah dan membentuk teritori tersendiri, sehingga pada lokus matan terdapat dua kategori teritorialitas yaitu primery territories pada zona III dan secondary territories pada zona II.

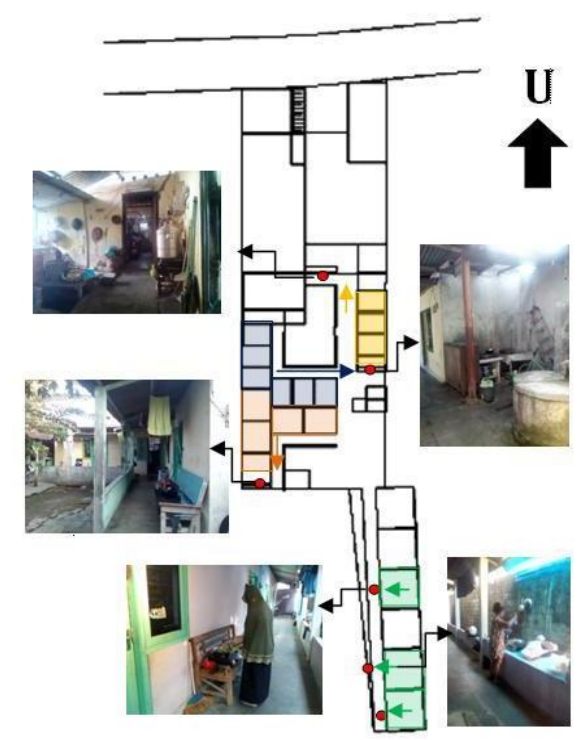

Gambar 7. Tempat memasak dan akses area kost.

Umumnya yang menggunakan tempat masak di tiap zona adalah ibu rumah tangga yang memasak untuk anak dan suaminya, dan yang dominan waktu penggunaan ruang masak terjadi pada pagi hari dan sore hari baik saat weekdays maupun weekends. Pada siang dan malam hari jarang terjadi aktivitas memasak, hal ini disebabkan karena penghuni lebih memilih makan di luar kost.

b. Mencuci

Tempat mencuci terdapat pada zona II dan III, yang membedakan adalah aksesnya karena jaraknya yang berbeda. 


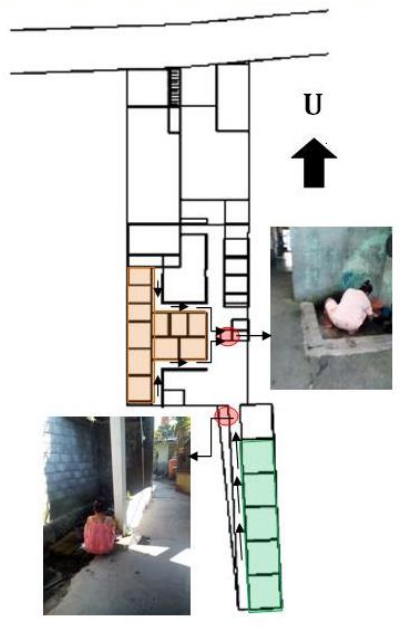

Gambar 8. Tempat mencuci dan akses pada area kost.

Pada zona II tempat mencuci digunakan secara bergantian oleh penghuni kost sehingga interaksi antar penghuni dapat terjadi di area ini, namun di zona III kondisinya lebih renggang dari penggunaan tempat cuci karena posisi kamarnya memanjang dan hanya terdapat satu tempat mencuci sehingga terkadang penghuni kost lebih memilih mencuci pirirng atau pakain di dalam kamar masing-masing di zona III.Hal lain yang membedakan adalah dengan alasan kebersihan sehingga meskipun aksesnya jauh membuat penghuni kost memilih mencuci piring di tempat cuci bersama. Hal tersebut yang membuat interaksi antar sesama penghuni menjadi kurang terjadi pada area ini.

c. Aktivitas mandi/MCK

Kamar mandi bersama hanya terdapat pada zona III, dengan jumlah unit kamar mandi yang disiapkan pemilik kost tiga unit, antrian saat menggunakan kamar mandi ini sering terjadi. Disisi lain intreraksi sesama penghuni sering terjadi, sambil menunggu antrian terkadang mereka mengobrol sambil duduk-duduk di area bersama (kursi). 


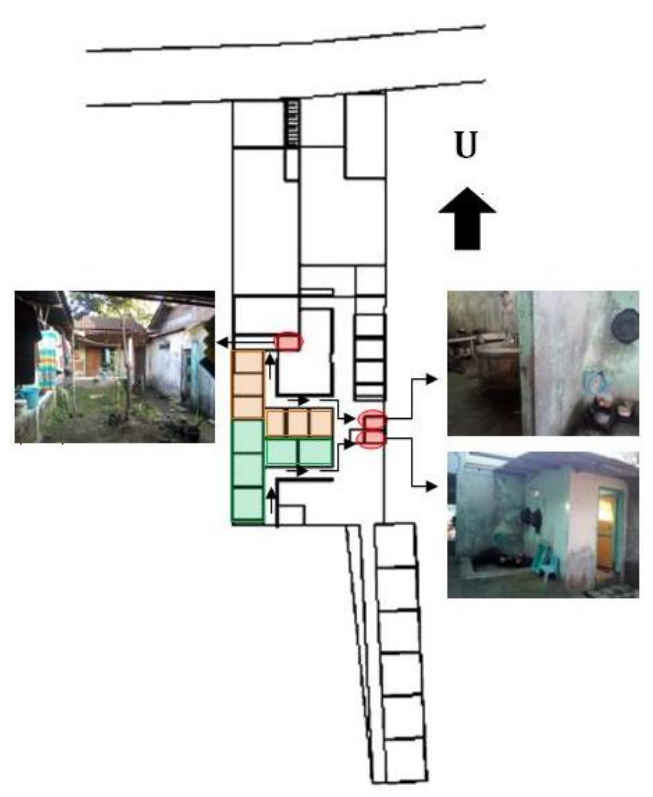

Gambar 9. Tempat MCK dan teritori area kost.

Pembagian kamar mandi ini, secara tidak langsung menjadikan kamar mandi sebagai area primery territories. Hal tersebut terjadi karena, penghuni pada unit tertentu terkadang merasa segan dan tidak berhak memasuki kamar mandi area unit lain. Yang menjadi batas teritori adalah tembok atau dinding dari tempat mencuci serta aksesnya.

d. Mengobrol

Mengobrol hanya terdapat pada gerbang pintu masuk utama kost, secara teritori termasuk dalam area privat pemilik kost. Namun karena ruang mengobrolnya terletak diantara sirkulasi atau jalan masuk zona II dan III sehingga menjadikan area mengobrol menjadi area publik dan secondary territories. Tempat mengobrol dijadikan sebagai ruang interaksi antara pemilik kost dan penghuni kost, karena terkadang penghuni diajak untuk ngobrol hanya untuk menanyakan kabar, kebutuhan umum kost dan kegiatan yang akan dikerjakan. Ada unsur kesengajaan dari setting fisik area ini, dilihat dari ada penambahan tempat duduk sebagai kontrol dalam mengamati penghuni kost yang keluar dan masuk area kost. Aktivitas mengobrol biasanya dilakukan pada sore hari baik saat weekdays maupun weekends. 


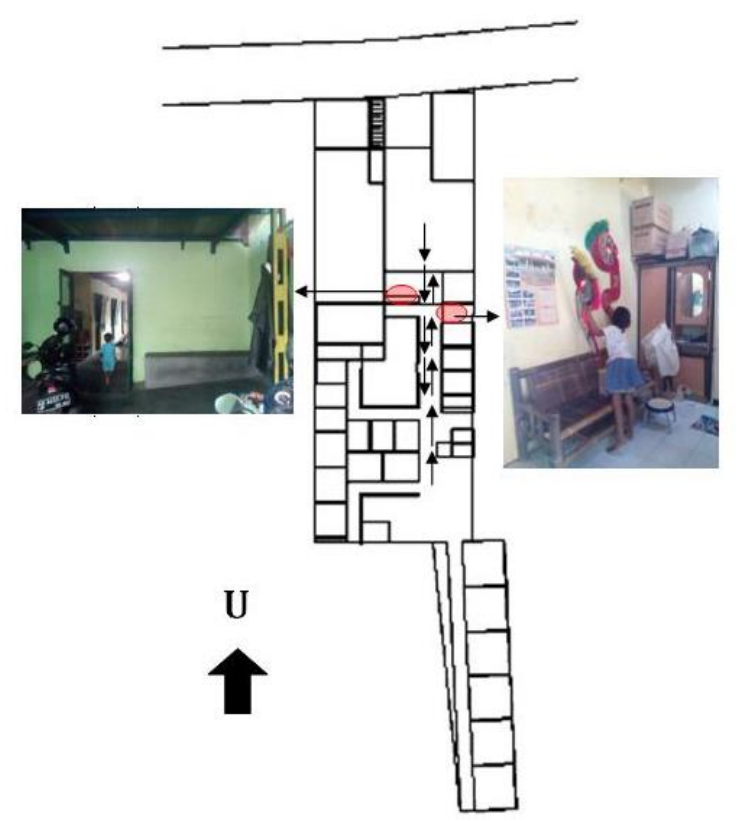

Gambar 10. Tempat mengobrol area kost.

Gerbang utama juga menjadi pengontrol interaksi sosial, ketika siang jika kondisi kost sedang sepi secara langsung anak dari pemilik kost menutup pagar agar orang lain yang tidak memiliki kepentingan tidak memiliki akses ke dalam kost. Sebelum melewati gerbang, penghuni atau orang yang akan masuk ke area kost terdapat kursi beton permanen yang dijadikan sebagai tempat duduk pemilik kost, meskipun intensitas penggunaan tempat mengobrol lebih banyak pada kursi sisi selatan gerbang.

e. Menjemur

Aktivitas pada ruang jemur tiap zona berbeda-beda, untuk zona I oleh pemilik kost menjemur hampir tiap hari karena usaha yang digeluti sebagai penyedia jasa loundry, di zona II ada yang menjemur tepat di depan unit kost dengan membentangkan tali yang dibatasi kolom sehingga tercipta teritori sendiri agar menjadi area privasinya dan ada yang menjemur di halaman yang lebih luas, bertujuan agar penggunaannya dapat dimiliki oleh pengguna lainnya. Berbeda dengan zona III yang area jemurnya lebih privat, karena sangat jelas pembatas teritorinya dari tiang yang dugunakan dan warna tali jemuran menjadi pembeda dengan yang lain. Zona II aktivitas menjemur biasanya dilakukan pada pagi hari setelah mandi, memasak dan mencuci piring. Sedangkan zona III waktu menjemur tidak menentu kadang pagi, siang bahkan menjemur yang paling sering dilakukan adalah pada malam hari. Berdasrkan hasil wawancara, pemilihan waktu menjemur malam karena waktu yang tepat untuk meniriskan baju pada malam 
hari agar siangnya cepat mengering dan juga karena waktu mereka mencuci dan menjemur hanya pada malam hari disebabkan oleh sering pulang saat sore karena bekerja.

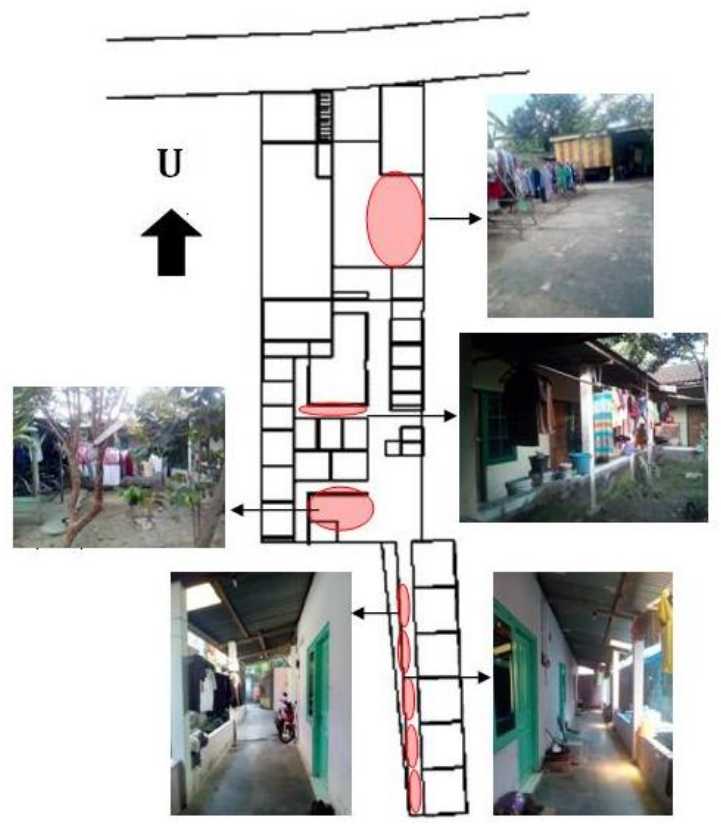

Gambar 11. Zonasi tempat jempur.

\section{f. Bermain}

Aktivitas yang menarik adalah ketika anak-anak dari penghuni kost bermain bersama di sepanjang area jalan dan selasar kost. Dari aktivitas ini banyak interaksi yang terjadi karena jangkauan dari bermainnya hampir memasuki seluruh area, sehingga tanpa disadari suasana menjadi cair tanpa memandang teritori ataupun kecanggungan antara sesama penghuni.

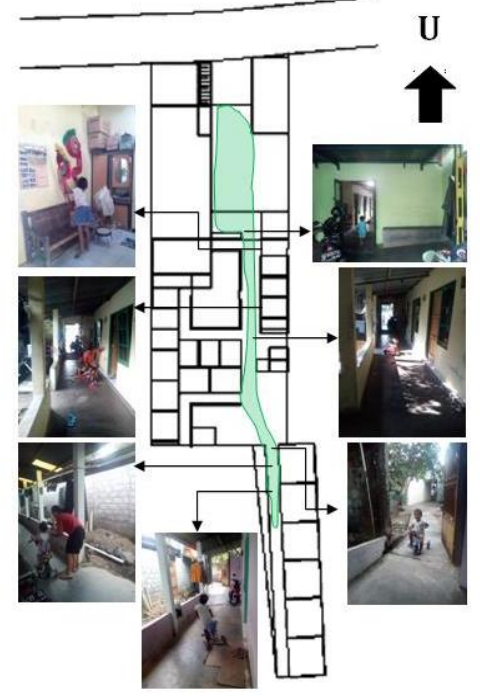

Gambar 12. Jangkauan area bermain anak. 
Karena hampir tidak ada interaksi karena faktor zonasi ruang dan tidak adanya kepentingan untuk saling menyebrang ke area penghuni lain. Terkadang orang tua penghuni memberi teguran agar anaknya tidak bermain di area lain, meski demikian anak-anak selalu melakukan aktivitas sesuai dengan keinginannya. Aktivitas yang biasa dimainkan adalah bermain sepeda dan bermain mobil-mobilan, dominasi area yang selalu digunakan pada zona II, sesekali masuk ke zona III dan zona I. Waktu bermain anak-anak biasanya lebih cenderung pada pagi hari sambil sarapan, sehingga pengawasan orang tua saat bermain lebih mudah terkontrol. Pada siang hari anak-anak penghuni asrama memilih istirahat di dalam kost, namun sesekali mengikuti kakek mereka pergi ke masjid untuk shalat atau beribadah. Pada sore hari saat weekdays anakanak banyak bermain di area zona I, permainan yang dilakukan adalah bermain mobil-mobilan sambil melihat anak-anak lain bermain layangan.

\section{KESIMPULAN}

Secara umum setting fisik ruang yang digunakan pemilik kost sudah terwakili dengan adanya beberapa fasilitas bersama, meskipun tidak semua disiapkan untuk penghuni. Pola keruangan adalah memanjang terpusat, artinya sirkulasi adalah sebagai pusat dan di kelilingi oleh unit-unit kamar. Untuk lebih mudah dalam pengontrolan, pemilik asrama membuat dua gerbang yang berbeda tepat sebelum masuk pada zona II dan memasuki zona III.

Dari hasil analisis dan wawancara, pemanfaatan fasilitas ruang bersama di masingmasing zona dapat disimpulkan, yaitu:

a. Ruang bersama zona I, untuk fasilitas warung makan dan loundry banyak digunakan oleh masyarakat di luar kost karena penghuni kost lebih memilih mencuci sendiri.Sedangkan tempat duduk keluarga yang berada di teras rumah pemilik kost secara teritori adalah milik pemilik kost, namun terkadang digunakan oleh penghuni kost meski hanya untuk duduk sejenak menunggu teman atau untuk melepas lelah. Selain itu, yang selalu digunakan oleh penghuni kost dari zona II dan III adalah fasilitas parkir zona I, digunakan dalam jangka waktu pagi, siang dan sore saja sedangkan malam hari dengan alasan keamanan penghuni kost lebih memilih memarkirkan kendaraan roda dua di zona masing-masing. Hanya fasilitas jemur yang tidak digunakan oleh penghuni dari zona-zona yang lain, karena fasilitas jemur zona I digunakan sebagai tempat jemur pakaian loundry. Sehingga kurangnya interaksi di zona I disebabkan oleh teritori, kurangnya kontak sosial dan komunikasi antar 
sesama penghuni maupun dengan pemilik asrama.

b. Ruang bersama zona II,proses interaksidi zona initerjadi pada ruang bersama seperti tempat masak, kamar mandi/MCK, tempat cuci dan ruang jemur pakaian.Tersedianya ruang bersama tersebut menyebabkan sering bertemunya antara sesama penghuni akan kebutuhan ruang bersama tersebut. Selain dari itu adanya ruang mengobrol keluarga penghuni kost yang membuat teritori sendiri sehingga setiap penghuni kost dari zona II dan III melewati area tersebut secara tidak langsung akan saling menyapa dan berkomunikasi minimal hanya sekedar meminta izin untuk lewat. Penggunaan ruang mengobrol ini hampir tiap sore saat weekdays dan weekends, sehingga memudahkan dalam mengontrol penghuni yang keluar masuk kost. Kegiatan bermain anak adalah yang paling mendominasi dalam penggunaan selasar yang panjang dan terspusat, waktu juga menjadi faktor yang penunjang terjadinya aktivitas yang dilakukan anak-anak maupun penghuni kost lainnya. Terkadang terjadi kontak fisik yang positif seperti senyum pada anak dan berjabat tangan untuk mengenal anak-anak yang bermain.

c. Khusus pada zona II proses interaksi lebih banyak dilakukan di area tempat mengobrol di samping gerbang pertama masuk zona II karena tidak berjauhan dari rumah pemilik kost dan juga sebagai pusat dari ruang bersama keluarga pemilik kost, selain itu selasar sebagai jalur sirkulasi juga sebagai penghubung interaksi antar zona karena terdiri dari satu jalur keluar dan masuk sehingga interaksi banyak terjadi di sepanjang selasar kost. Sehingga perbedaan aktivitas berpengaruh terhadap pemanfaatan ruang bersamadan luasan jangkauan pengguna.

d. Ruang bersama zona III, pada zona III terkesan lebih tertutup dan lebih banyak menghabiskan waktu kesehariannya di luar kost maupun di dalam kost, sangat jarang terjadi interaksi pada area ini. Faktor utama kurangnya interaksi adalah waktu pulang kerja pada malam hari,kurangnya penggunaan tempat mencuci piring, tempat jemuran dan tempat masak sesuai teritori masing-masing. Hanya fasilitas parkir yang digunakan oleh seluruh penghuni pada zona III ini. 


\section{DAFTAR PUSTAKA}

Altman (1975) The Environment and Social Behavior: Privacy, Personal Space, Territory, Crowding. Brooks/Cole Publishing Company, University of Utah, California.

Carmona, et al. (2003) Public places - urban, the dimention of urban design. Architectural press.

Gunawan S. (2004) Penataan Ruang Publik Yang Memadukan Pola Aktivitas Dengan Perubahan Fisik Kawasan Kasus Kawasan Tambak Bayan-Babarsari, Seminar dan Lokakarya Nasional Ikatan Arsitek Indonesia, hal. 1-19.

Lang, Jon (1987)Creating Architectural Theory: The Role of the Behavioral Sciences in Environmental Design. Van Nostrand Reinhold Company, New York.

Trancik, Roger (1986) Finding Lost Space: Theories of Urban Design. Van Nostrand Reinhold Company, New York. 